THURSDAY, JANUARY I6, 1879

\section{A SCOTTISH METEOROLOGICAL MOUNTAIN OBSERVATORY}

$T^{T}$ is the opinion of those best versed in meteorological 1 science, that much valuable information regarding the constitution of the earth's atmosphere, and the laws which determine the changes in the atmosphere, is to be obtained by observations at elevated stations. To quote the words of the distinguished French philosopher, Biot: "It is in the high regions of the air that meteors are formed, rain, snow, and hail. There the thunder rolls and the lightning traces its furrows. There the aurora displays its plume of light, and the aerolite shines and bursts. There are the upper currents which chariot the clouds. It is to these elevated regions that the inquirers of meteorological science ought to be directed."

For want of permanent stations at high levels, attempts have been made to explore the upper regions of the atmosphere in balloons. In the year $1862, M r$. Glaisher-at much personal peril-accomplished about thirty ascents with instruments which enabled him to ascertain with some precision the aerial temperature, humidity, clouds, and other phenomena, up to a height of several miles. More recently, Tissandier, in France, made twenty-four ascents in balloons, also with the result of obtaining valuable information on these points. Since February; 1877 , Secretan, an enterprising optician in Paris, has been sending up small exploring balloons, for ascertaining the height of clouds and the direction of the aerial currents up to about 1,200 metres.

The value of the data obtained by these casual explorations has led meteorologists to a more systematic study of the upper regions of the atmosphere.

Thus Dr. Hildebransen? of Upsala has been devoting himself to a study of clouds, to ascertain thcir altitude, movements, and shapes at different seasons; and he has recently issued a circular to meteorologists in other countries, pointing out the importance of the inquiry, and inviting co-operation.

It has been recently discovered in France, by observations at the Montsouris Observatory, that dust of various kinds is at most seasons of the year floating in the atmosphere, consisting of spherules so minute as to be discernible only by the microscope or by chemical tests: and that which so floats is not always the same in the higher as in the lower regions of the air. The bearings of this new information on epidemics affecting both animal and vegetable life is awakening much attention among continental physicists.

These remarks refer to the information afforded by meteorological observations at high stations regarding the constitution of the atmosphere or the ingredients existing in it. But there is another use to which highlevel stations can be and are applied, viz., to furnish early intimation of changes in the weather. It appears from the observations made at the high-level stations of the Scotch Meteorological Society, that changes of temperature take place in the upper regions from twenty-four to thirty-six hours sooner than in the same district at Vox. XIX.-No, $48 \mathrm{I}$ ordinary low levels. Lately Prof. Loomis has been comparing the observations made at high-level and low-level stations in America, and he finds a considerable difference, not only in the speed and direction of the wind, but even in the barometric pressure.

In these circumstances it is not surprising that scientific meteorologists in all countries should in addition to lowlevel stations have made strenuous efforts to obtain also stations at high levels, and that they have been to a large extent successful. Thus in France two meteorological stations have lately been formed on the Puy de Dôme and the Pic du Midi, at heights respectively of 4,809 and 9,439 feet above the sea. In Austria Dr. Hann, one of the ablest European meteorologists, with Government aid, established a station in Upper Carinthia at a height of $8, \infty 00$ feet above the sea. There are three stations in Italy, at heights respectively of $7,087,8,343$, and 8,360 feet above the sea, and a fourth is about to be established on Mount Etna, at the Casa Inglese, at a height of 9,652 feet above the sea. In Switzerland there is a station at the Hospice of St. Bernard, at 8, r 30 feet above the sea. In the United States the meteorological station at Mount Washington is 6,600 feet, Mount Mitchell 6,69I feet, and at Pike's Peak (Colorado State), 14,216 feet above the sea; all of these stations were established by the fovernment, which also supplies instruments and pays the observers, who are soldiers.

Such being the state of matters in foreign countries as regards high-level stations, what is the case in Great Britain? It is believed that in England the highest meteorological station is 1,372 feet above the sea; and that in Scotland the two highest are, respectively, I,334 and I,450 feet. If: is matter of regret that in both England and Scotland there should not be stations at higher points, seeing that there are in both countries favourable positions for such. That regret has been repeatedly expressed by dithorities to whose opinion some regard might have been expected to be paid. In February, 1877 , the president of the English Metcorological Society, in his address to the Society, pointed out that "the most obvious way of gaining a clearer insight into the condition and movements of the gaseous envelope of the earth, is by the establishment of observatories on isolated mountain peaks. The value of this arrangement had been practically recognised abroad, and might well be imitated on some of our highest hills, such as Skiddaw in the north of England, or on the western seaboard of Ireland or Scotland, where. their fitness as outposts, for giving early indications of storms from the west, would soon be appreciated."

The suggestion of high-level stations has been repeatedly made by the Scotch Meteorological Society. Thus, in July, 1875, the Chairman of that Society, after alluding to the value of the observations at the American high-level stations, observed that, so impressed was the Society's Council with the importance of high-level stations, that, if funds were forthcoming, "probably the very first thing which the Council would endeavour to do would be to establish stations on the two highest points of Scotland, viz., Ben Neris on the west coast, and Ben Macdhui on the east coast, and, by means of intermediate stations on the sides of these mountains, obtain, as suggested by Mr. Stevenson, vertical meteorological sections of the atmosphere." 
Again, at a general meeting of the Scotch Society in July, 1877 , the Chairman, in his address, renewed his reference to the desirability of a station on, at all events, Ben Nevis, and mentioned that Lord Abinger, the proprietor, having consented to the erection of a hut for the purpose, "the Society's Council would readily establish the station if it only had the requisite funds." Testimony to the value of high stations has in like manner been given by Mr. Robert Scott, the Secretary of the Government Meteorological Department.

Mr. Scott was the first and principal witness examined before the recent Government Meteorological Commission, and his opinion on the point of high-level stations is shown by the following questions and answers :-

Q. Has the Meteorological Committee felt it desirable to have stations at some higher levels in Great Britain?

A. Certainly they have.

$Q$. Have they thought of any particular plan?

$A$. They have had no money for it.

Q. Have they thought of any place if the y had money?

A. I may mention Settle, because there is a telegraph station there, a high-level station, about $\mathrm{I}, 000$ feet above the sea, on the borders of Yorkshire and Lancashire. If ever we had $30 l$. a year to spare, we should like to have a station there. It is found in cold weather that warm weather sets in at the upper stations perhaps one or two days before it comes down.

When such are the opinions which have been expressed and brought before the country by authorities deserving of respect and attention, it is hoped that the establishment of high-level meteorological stations will be no longer delayed. It is true that none of the mountains in the United Kingdom are so high as in the other countries above enumerated where high-level stations have been and are about to be established. But on the other hand the British Isles occupy a position more important for meteorological purposes than almost any other European country, inasmuch as their westward position enables British meteorologists to obtain the earliest information regarding the great storms which sweep across the Atlantic, and of which warning as soon as possible should be given in Europe. Great Britain's duty, interest, and credit as a nation concur therefore in this matter; and it is hoped that measures will soon be taken to establish these high-level stations in the three divisions of the United Kingdom, unless, in fact, we are prepared to see the problems presented by the phenomena of the bigher air worked out in other countries.

\section{COAL}

Coal: its History and Uses. By Professors Green, Miall, Thorpe, Rücker, and Marshall, of the Yorkshire College. Edited by Prof. Thorpe. (London : Macmillan and Co., 1878.)

THALL be much surprised if this composite little 1 volume fails to attract the attention of many students of nature, but especially of such persons as are practically connected with coal, either as students, as proprietors, or as workers. The five professors of the Yorkshire College of Science who have combined to produce the volume are men thoroughly competent to deal with the portions of the subject which they have severally undertaken, and the result of their labours is a book at once picturesque and scientific.

Prof. Green commences the work by two chapters on the geology of coal. After dealing with the general phenomena of the deposition of sandstones, shales, and limestones, he proceeds to examine the special features of coal and the probable conditions attending its formation. In doing so he grapples with the peculiar questions connected with the well-known lamination of coal and the alternation of the brittle, lustrous, bituminous layers with those of the so-called mother-of-coal or mineral charcoal. This subject of course raises the question of the origin of these two elements-a question which still presents curious and unsolved difficulties. The mineral charcoal chiefly consists of cubical fragments of bark mingled with some vascular or woody elements of plant-stems. Prof. Green correctly points out that "the woody character of this mother of coal is palpable even to the unaided eye," further adding "that it is possible, in some cases, to say what the plant was of which they (i.e., the fragments of charcoal) originally formed a part." I am afraid that this latter feat is not easily performed. The vascular tissues which we chiefly find in this mineral charcoal are not those seen in Lepidodendron and in Sigillaria. The absence of the latter structures is one of the facts not easily explained. The vessels forming the ligneous zones of these two representatives of the carboniferous flora are always of the barred or pendoscalariform type. The dominant element in the mineral charcoal consists of the various modifications of cellular tissue found in the bark of these, and many other unrecognisable, plants, but the vessels are mainly of the reticulated type. They closely resemble the vascular elements found in some Calamites, in most Asterophyllites and Sphenophylla, and in all the known Lyginodendra. Whether the barred vessels of the Lycopodeaceous plants did not form a part of the vegetable mass converted into coal, or whether, being there, they were, bituminised more readily than others, is not easy to say. I am inclined to believe in the latter explanation; anyhow, I have as yet failed to find a solitary fragment of one of these barred vessels in the mineral charcoal. A fragment of American coal, sent to me many years ago by that distinguished microscopist, Dr. Bailey, of West Point, consisted wholly of numerous layers of similar reticulated vessels which had not undergone bituminous disintegration. The laminæ of mineral charcoal alternate with those of the more bituminised coal with great irregularity; in some specimens they are distributed in about equal quantities, in others thick bituminous layers separate the charcoal layers very widely. Whatever the agency may have been that brought about the result, this lamination shows that, in most instances, there have been irregularly recurring periods when innumerable, perfectly carbonised, but only partially disorganised, fragments of certain decaying stems were strewed over the surfaces of those portions of the vegetable mass which became converted into the more bituminous laminæ of the coal. In other cases I find no difficulty in seeing the charcoal intermingled with, and actually undergoing conversion into, the bituminous condition, whilst interposed layers of perfect macrospores have undergone no such conversion. The charcoal fragments are 